\title{
The environmental effectiveness of alternative agri-environmental policy reforms: theoretical and empirical analysis
}

\author{
Jussi Lankoski \\ Agricultural Economics Research Institute, PO Box 3, FIN-00411 Helsinki, Finland, e-mail: jussi.lankoski@mttl.fi \\ Markku Ollikainen \\ Department of Economics, PO Box 54, FIN-00014 University of Helsinki, Finland
}

\begin{abstract}
This paper analyzes alternative agri-environmental policy reforms to reduce nutrient runoff when the government has price support, fertilizer tax, buffer zone subsidy and acreage subsidy as available instruments. To promote environmental goals, the government is assumed to adjust the tax and subsidy rates so as to keep the farmer's profits constant. This instrument switch reduces the prices of lesspolluting inputs and the farmer re-optimizes his production so that it becomes more environmentally friendly. The four alternative reforms under study are the following: a reduction of the producer price support or acreage subsidy compensated for by a higher buffer zone subsidy, and an increase in the fertilizer tax which is compensated for by either a higher acreage subsidy or a buffer zone subsidy. We show theoretically that although all reforms reduce the nutrient runoff, the last one is the most efficient. Our simulations show that at a $30 \%$ abatement level of nitrogen runoffs all policy mixes decrease the average farmer's profits after the re-adjustment, if the end price is not allowed to increase due to decreased production. The smallest loss in the farmer's profits results from a policy mix which compensates for the higher fertilizer tax by a higher acreage subsidy.
\end{abstract}

Key words: acreage subsidy, agri-environmental policy, buffer zone, fertilizer tax, nitrogen runoff

\section{Introduction}

Recent agricultural policy and trade reforms can improve the environmental performance of the agricultural sector. Through re-instrumentation of domestic agricultural policies from market price supports to decoupled direct payments, agricultural policy and trade reforms can be used to reduce some adverse environmental effects associated with agriculture. However, targeted agri-environmental policies still play an important role in internalizing environment-related agricultural externalities. Most OECD member countries have introduced agri-environmental measures and programs in recent years. As direct payments are increasingly linked to environmental objectives, there has also been a concern that some of these payments may distort production decisions and agricultural trade. 


\section{Lankoski, J. \& Ollikainen, M. The environmental effectiveness of agri-environmental policy reforms}

Agricultural water pollution is a typical example of nonpoint source pollution, which makes controlling and monitoring it very difficult. Hence, traditional direct instruments, such as effluent standards and effluent taxes, are inapplicable in agriculture. When effluents cannot be addressed directly, the regulator has to use indirect instruments, for example input and ambient taxes and standards on farming practices (see Segerson 1988, Braden and Segerson 1993 for general analysis and Vatn et al. 1997 for applied research and interdisciplinary modelling of agricultural nonpoint pollution).

One of the major objectives of the Finnish application of European Union agri-environmental regulation EEC 2078/92 is the reduction of nutrient runoffs. In what follows we assume that the government follows the principle of least distortions on production and trade, and that it issues decision-in-principle water protection targets for the reduction and prevention of eutrophication with the main goal of reducing nutrient runoffs from agriculture. From this starting point we analyze how this kind of agri-environmental reform should be executed by focusing on those policy instruments that are appropriate for achieving this goal (acreage subsidy, price support, fertilizer tax and buffer zone subsidy). Specifically, we assume that the government adjusts the relative rates of taxes and subsidies so that these adjustments per se keep the farmer's profits constant. Consequently, however, the relative prices of inputs change so that the environmentally friendlier input use becomes more profitable and the farmer re-optimizes his input use. We characterize alternative tax/subsidy mixes qualitatively and quantitatively by an empirical simulation experiment. The analysis is based on a standard profit maximization model of a representative farmer. The theoretical core of this paper is based on Ollikainen (1999), but we elaborate it in many ways. First, we include capital as a third production factor in addition to cultivated land and fertilizer. Second, we analyze not only the environmental effects but also the agricultural output supply, and third, we offer a numerical simulation for further evaluation of the alternative agri-environmental policy mixes in terms of output, profits and environmental effects.

From this point onwards the paper is organized as follows. The private optimum of agricultural production in the presence of agri-environmental measures is analyzed in section 2 . Government impact-neutral (net support-constant) agri-environmental policy reforms are then analyzed in section 3 by comparing the environmental effectiveness of alternative policy mixes. Section 4 presents a simulated quantitative assessment of the effects of alternative agri-environmental policy mixes. Section 5 concludes with a brief discussion.

\section{The model of agricultural production}

Consider a competitive farm producing cereals using fertilizer $l$ and capital $k$ as inputs in the production. The total amount of arable land $q$ is fixed, and the farmer can allocate it to cereal production $\hat{q}$ and to a buffer zone $m$ ( $\mathrm{m}$ is a share of total arable land) so that the acreage under cereal cultivation is $\hat{q}=(1-m) q$.

The production function is given by

$Q=f(l, \hat{q}, k)$

where $Q$ denotes the cereal produced. Cereal production depends on fertilizer and capital use per hectare and on the acreage under the cereal cultivation. The production function is assumed to be concave in its arguments, that is, each factor of production exhibits diminishing marginal productivity and the production function is linear homogeneous. Thus we have

$f_{l}, f_{k}, f_{q}>0 ; f_{l l}, f_{k k}, f_{q q}<0$,

so that for the buffer zone it holds that $f_{m}=-q f_{q}<0 ; f_{m m}=q^{2} f_{q q}<0$.

We make the following assumptions concern- 
Vol. 8 (1999): 321-331.

ing the cross-derivatives. Fertilizer and capital are assumed to be independent of each other, i.e., their cross-derivative is zero. The same is assumed to hold for capital and soil. This can be justified on the grounds that technological improvements like precision farming are not feasible in the short run and thus an increase in capital does not increase the marginal productivity of soil. The cross- derivative of fertilizer and soil is positive, implying that these inputs are complements to each other. Thus, an increase in fertilizer use increases the marginal product of soil. The cross-derivative between fertilizer use and land allocated to the buffer zone implies that an increase of the buffer zone area decreases the land under cultivation and hence, the total use of fertilizer. Summing up, we impose that $f_{l k}=0=f_{q k}$, and $f_{l m}=-q f_{l q}<0$.

As the representative farmer is a price taker, the prices of fertilizer $c$, capital $r$ and cereal $p$ are exogenous for him. The government pays a price support $a$ so that the unit price of cereal is $p^{*}=p(1+a)$. Moreover, a fertilizer tax $t$ is levied on fertilizer use so that the after-tax price of fertilizer is $c^{*}=c(1+t)$. The government pays a buffer zone subsidy $b$ for a managed, uncultivated area covered by perennial vegetation between arable land and watercourses or in groundwater areas. The cultivated arable land is entitled to a unit acreage subsidy $s$. The farmer's problem is to choose the input use of $l, k$ and $m$ to maximize the farm's profit, i.e.,

$$
\underset{\{l, k, m\}}{\operatorname{Max}} \Pi=p^{*} f(\hat{q}, l, k)-c^{*} l \hat{q}-r k+b m q+s \hat{q} .
$$

First-order conditions for the optimum solution are

$$
\begin{aligned}
& \Pi_{l}=p^{*} f_{l}-c^{*} \hat{q}=0 \\
& \Pi_{k}=p^{*} f_{k}-r=0 \\
& \Pi_{m}=-p^{*} q f_{q}+c^{*} l q+(b-s) q=0 .
\end{aligned}
$$

These first-order conditions require that the value of the marginal product of fertilizer and capital use equals the cost of fertilization and the price of capital, respectively. Moreover, the land allocated to the buffer zone will be increased to the point where the sum of the reduction of the value of the marginal product of cultivating cereal and the savings in fertilization costs equals the difference between the buffer zone subsidy and acreage subsidy. Since the value of marginal product of cultivating cereals is greater than the costs of fertilization, the buffer zone subsidy must be greater than the acreage subsidy for an interior solution.

\section{Comparative statics of input use}

Given that the second-order conditions hold, the comparative-static analysis can be carried out to yield (see Appendix 1 for details)

$$
\begin{gathered}
l=l\left(\begin{array}{c}
p, c, r, b, s, t, a \\
+
\end{array}\right) \\
k=k\left(\begin{array}{c}
p, c, r, r, b, s, t, a \\
+0
\end{array}\right) \\
m=m\left(\begin{array}{c}
p, c, r, b, s, t, a \\
+ \\
+ \\
+
\end{array}++-\right.
\end{gathered}
$$

Equation [5] shows that input demand depends on exogenous parameters in the usual way, i.e., the own-price effects are negative. Specifically, the use of fertilizer and capital depends positively on the output price, while the size of the buffer zone is negatively related to it. Increasing the buffer zone subsidy results in reduced fertilizer use and a larger buffer zone. An increase of acreage subsidy boosts the use of fertilizer and decreases the buffer zone area, whereas a fertilizer tax has the opposite effects. A higher producer price support $a$ increases the use of fertilizer and capital and decreases the land area allocated to the buffer zone. Thus, the acreage subsidy and producer price support tend to reenforce environmental distortions, since they encourage the use of fertilization and discourage the allocation of arable land to the buffer zone.

\section{Comparative statics of output supply}

The comparative-static analysis of output supply (see Appendix 2, equation [A3]) shows that 
Lankoski, J. \& Ollikainen, M. The environmental effectiveness of agri-environmental policy reforms

output supply depends on exogenous parameters in the conventional way: increases in factor prices, fertilizer tax and buffer zone subsidy will decrease supply, while increases in output price, producer price support and acreage subsidy will increase output supply.

\section{Environmental effectiveness of alternative agri-environmental policy mixes}

Assume now that the government issues decision-in-principle water protection targets for the reduction and prevention of eutrophication and wishes to design an agri-environmental reform by changing the tax/subsidy base according to two guiding principles. First, the reform should follow the principle of least distortion caused to production and trade, i.e., production is not allowed to increase. Second, the changes in the tax and subsidy rates to favor environmentally friendlier production should be made so that the farmer's profits remain constant before the farmer adjusts his input use. Before going into a detailed analysis of the reform, we must clarify first how to model the nitrogen runoff from the fields.

\section{Runoff function of nutrients}

Consider the following runoff function for nutrients

$z=g(l, \alpha, m)$.

This formulation, based on an economic interpretation of empirical runoff studies, was first proposed in Ollikainen (1995). According to [6], the runoff, $z$, depends on three factors: fertilizer use $l$, the declivity of fields near watercourses $\alpha$ and the size of the buffer zone $m$. The runoff depends positively on fertilizer use and on the declivity coefficient, and negatively on the size of the buffer zone. The declivity coefficient can be regarded as a function of the buffer zone: the larger the area allocated to the buffer zone, the smaller the impact of the declivity coefficient on runoff, so we have $\alpha=\alpha(m)$. Thus, the runoff from fields can be described as a function of fertilizer use $l$ and $\alpha(m)$. The runoff function is assumed to be convex in $l$ and concave in $\alpha(m)$ :

$z=\alpha(m) g(l)$

where $g^{\prime}(l)>0 ; g^{\prime \prime}(l)>0$

$\alpha^{\prime}(m)<0 ; \alpha^{\prime \prime}(m)>0$.

According to Gilliam et al. (1997), buffer zones are very effective in the removal of sediment-associated nitrogen from surface runoff and nitrate from subsurface flows, and removals of $50-90 \%$ have been common. However, the effectiveness of buffer zones in removing nutrients from surface and groundwater is highly dependent on hydrology. For example, surface flows should occur as sheet flow rather than focused flows, and groundwater should move at a slow speed through the buffer in order to remove nitrates effectively (Correll 1997). According to Hill (1996), vegetation uptake and microbial denitrification are two major mechanisms in buffer zones for removing nitrates from subsurface water, however, the relative importance of these two processes is uncertain. Moreover, as pointed out by Gilliam et al. (1997), the increased denitrification in buffer zone areas may trade water pollution for atmospheric pollution due to increased generation of $\mathrm{N}_{2} 0$.

In Finland, Uusi-Kämppä and Yläranta (1992, 1996) have analyzed the reductive effects of a grass buffer zone 10 meters wide on sediment and nutrient losses. Barley and oats were cultivated on experimental fields during the experimental period with fertilization levels of 90 $\mathrm{kg}$ of nitrogen per hectare and $18 \mathrm{~kg}$ of phosphorus per hectare. A grass buffer zone reduced surface runoff of total nitrogen and nitrates by 50 per cent. It is important to note that buffer zones reduce only surface runoff of nutrients but not runoff through drainage pipes. For example, 
Vol. 8 (1999): 321-331.

in Finnish experiments measuring total nitrogen runoff from cultivated fields, over 50 per cent ran through drainage pipes (see e.g. Turtola and Jaakkola 1985, Turtola and Puustinen 1998).

\section{Environmental and supply effects of alternative policy mixes}

The principle of changing the relative tax and subsidy rates so that the farmer's profits remain constant implies that when one instrument entering into his profit function is increased, then another instrument is decreased so that his profits remain constant. This kind of switch in the tax/subsidy rates changes the relative prices of inputs in favor of environmentally friendlier production, leading the farmer to re-optimize his input use. Hence, after re-optimization, the farmer's profits may be higher or lower than before the reform, even though the government's net impact on the profit function was kept unchanged. Notice also that the government budget revenue constraint is not hold binding. This means that, after the farmer has re-optimized his input use, the required overall net support may be higher or lower than before the policy reform. Hence, this reform can be interpreted to reflect a situation where the government finds the size of environmentally adjusted agriculture to be optimal and allows the overall net support to adjust as necessary. The basic features of this policy are outlined in equations [8]- [10].

Differentiating the profit function [3] with respect to $t, b, s$, and $a$, while keeping the profits constant, gives the following differential equation to guide the instrument switches

$0=p f(\cdot) d a-c l \hat{q} d t+m q d b+\hat{q} d s$

The resulting change in the agricultural runoff of nutrients is given through changes in fertilizer use and buffer zone area

$$
d z=\underbrace{\alpha^{\prime}(m) g(l)}_{(-)} d m+\underbrace{\alpha(m) g^{\prime}(l)}_{(+)} d l,
$$

where the adjustment in the farmer's use of fertilizer $(d l)$ and the buffer zone $(d m)$ is given by the following differential equations, in which $i$ and $j$ denote the policy instruments that the government is adjusting

$$
\begin{aligned}
& d l=l_{i} d i+l_{j} d j \\
& d m=m_{i} d i+m_{j} d j
\end{aligned}
$$

In what follows we study the qualitative effects of four alternative agri-environmental policy reforms. First, the producer price support or acreage subsidy is reduced, and the environmentally motivated buffer zone subsidy is increased to compensate for this reduction. This derivation is followed by the analysis of fertilizer tax increase, which is compensated by an increase in acreage subsidy and buffer zone subsidy, respectively.

A decrease in the producer price support and an increase in the buffer zone subsidy

Due to intensification effects and related nutrient runoff the government wishes to switch from producer price support towards buffer zone subsidy while keeping profits constant. From *) mqdb + pf $(\bullet) \mathrm{da}=\mathrm{O}$ we obtain the required compensation to keep the profits constant, i.e.:

$d a=-\frac{m q}{p f(\cdot)} d b$.

Using [11] in [10] and applying comparative static results from input use (equation [5]) produces

$$
\begin{aligned}
& \frac{d l}{d b}=\left[-\frac{m q}{p f(\cdot)} l_{(+)}+l_{(-)}\right]<0 \\
& \frac{d m}{d b}=\left[-\frac{m q}{p f(\cdot)}{\underset{(-)}{a}+}_{(+)}+m_{b}\right]>0 .
\end{aligned}
$$

Applying these results to equation [9] yields the following effect on agricultural nutrient runoff:

$$
d z=\underbrace{\alpha^{\prime}(m) g(l)}_{(-)} \frac{d m}{d b}+\underbrace{\alpha(m) g^{\prime}(l)}_{(+)} \frac{d l}{d b}<0 .
$$

Thus, a switch from a producer price support towards a buffer zone subsidy decreases the use of fertilizers and increases the buffer zone area, 
Lankoski, J. \& Ollikainen, M. The environmental effectiveness of agri-environmental policy reforms

resulting in unambiguously reduced nutrient runoffs. The shift also reduces output supply, which, in the case of overproduction of cereals and constraints on the use of export subsidies, may be appealing to the government.

A decrease in the acreage subsidy and an increase in the buffer zone subsidy

Due to the production-stimulating and negative environmental side effects of acreage subsidy the government switches from it to buffer zone subsidy. Applying the same procedure as given in the previous policy reform one obtains

$$
\begin{aligned}
& \frac{d l}{d b}=\left[-\frac{m}{(1-m)} l_{(+)}+l_{(-)}+l_{b}\right]<0 \\
& \frac{d m}{d b}=\left[-\frac{m}{(1-m)} m_{(-)}+m_{b}\right]>0 .
\end{aligned}
$$

Using these results in equation [9] shows that both the runoff and the output decrease unambiguously.

An increase in the fertilizer tax and a raise in the acreage subsidy

Assume now that the government increases the fertilizer tax and compensates this by increasing the acreage subsidy. From equations [15a] and [15b] it can be seen that the effects are ambiguous, at first, but by using comparative static results (see appendix 3 for details of proving the sign) the signs of the effects are

$$
\begin{aligned}
& \frac{d l}{d s}=\left[\frac{1}{c l} l_{t}+l_{s}\right]<0 \\
& \frac{d m}{d s}=\left[\frac{1}{c l} m_{t}+m_{s}\right]>0 .
\end{aligned}
$$

Hence, this switch also results in unambiguously reduced nutrient runoffs according to [9]. However, the effect may now be weaker than in the previous cases since the increase in the acreage subsidy reduces the impact of the fertilizer tax. The output supply decreases as well, but this reductive effect may be weaker than in the previous cases due to production-stimulating effects of the acreage subsidy (see Appendix 2).
An increase in the fertilizer tax and an increase in the buffer zone subsidy

Consider now an alternative, where the government establishes its environmental policy reform by increasing the fertilizer tax and compensating this by increasing the buffer zone subsidy in order to have a substantial reduction in nutrient runoff. This leads to

$$
\begin{aligned}
& \frac{d l}{d b}=\left[\frac{m q}{c l q} l_{(-)}+l_{(-)} l_{b}\right]<0 \\
& \frac{d m}{d b}=\left[\begin{array}{cc}
\frac{m q}{c l \hat{q}} m_{t+}+m_{b} \\
(+)
\end{array}\right]>0 .
\end{aligned}
$$

As in the previous cases, applying these results in equation [9] results in unambiguously reduced nutrient runoff. However, in this case the reductive effect on nutrient runoff is stronger, since the fertilizer tax and buffer zone subsidy reinforce each other. Naturally, the output supply decreases as well, and the effect is stronger than in the previous cases (see Appendix 2).

Based on the qualitative analysis, we can conclude that a policy mix of equation [16a] and [16b] is superior in terms of achieving the environmental goals, but it reduces output more than other mixes. As we cannot rank the other alternative reforms qualitatively, it is useful to conduct an empirical analysis.

\section{Evaluating the environmental effects and net-support needs of agri-environmental policy: a simulated example}

To illustrate and compare numerically the environmental and economic effects of alternative agri-environmental policy reforms, the economic model of the representative farmer developed earlier in this paper is extended to include a model of nitrogen runoff. This extended model is then used to simulate $30 \%$ abatement of ni- 
Vol. 8 (1999): 321-331.

Table 1. Simulation parameters.

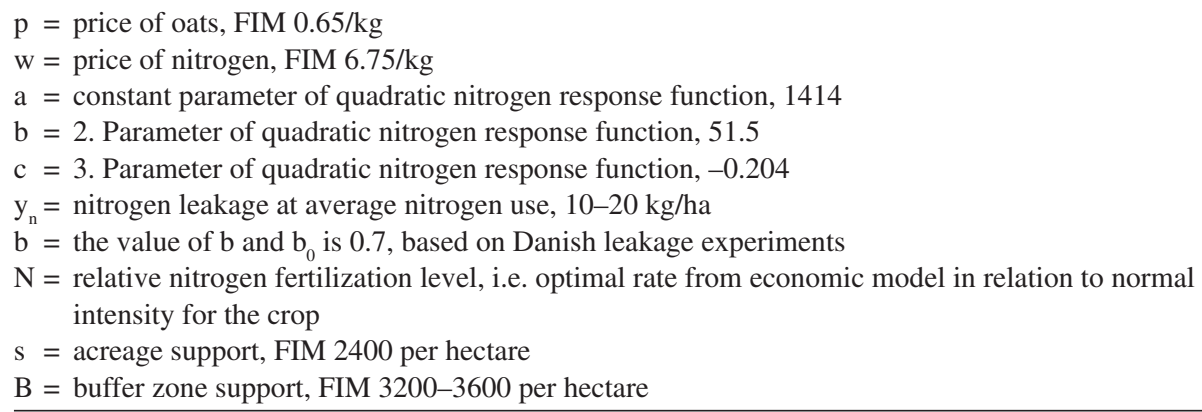

Notes: Prices and support figures are from 1998. Price of nitrogen is calculated from compound fertilizer N-P-K. Acreage support is calculated for the C2-area and it includes Common Agricultural Policy (CAP) compensation payments, the less favored areas (LFA) support, Environmental aid, and National support. Sources: Bäckman et al. 1997, Ministry of Agriculture and Forestry, Association of Rural Advisory Centres.

trogen runoffs - to reflect the reduction target for nitrogen runoff of the General Agricultural Environment Protection Scheme of Finland. We simulate government impact-neutral policy mixes derived in the previous section by using Finnish data. We also analyze what is the need for the increase in the government net support if one requires that, in spite of reduced production, farm income must remain unchanged after the readjustments of the input use. This alternative is called a farm revenue-neutral reform.

We use the nitrogen leakage function estimated by Simmelsgaard (1991) on the basis of Danish leakage research,

$y(N)=y_{n} \exp \left(b_{0}+b N\right)$,

where y $(\mathrm{N})=$ nitrogen leakage at fertilizer intensity level $\mathrm{N}, \mathrm{kg} / \mathrm{ha}, \mathrm{y}_{\mathrm{n}}=$ nitrogen leakage at average nitrogen use, $\mathrm{b}_{0}=\mathrm{a}$ constant $(<0), \mathrm{b}=\mathrm{a}$ parameter $(>0)$, and $\mathrm{N}=$ relative nitrogen fertilization in relation to normal fertilizer intensity for the crop, $0.5 \leq \mathrm{N} \leq 1.5$.

This leakage function measures changes in nitrogen leakages solely as a function of the fertilization intensity level. Information on average fertilizer intensity and nitrogen leakages from average nitrogen use $y_{n}$ is needed when applying this function to Finnish conditions. In the Finnish experimental studies on nitrogen leaching the average nitrogen fertilization level for cereals has usually been $100 \mathrm{~kg} / \mathrm{ha}$. Combined surface and drainage nitrogen leakages $\left(\mathrm{y}_{\mathrm{n}}\right)$ at this level have been in the order of $10-20 \mathrm{~kg}$ $\mathrm{N} / \mathrm{ha}$ (Sumelius 1994). In this simulation example, however, the average level of nitrogen fertilization was set at $90 \mathrm{~kg} \mathrm{~N} / \mathrm{ha}$ according to the fertilizer application criterion of the GAEPS (the General Agricultural Environment Protection Scheme of Finland).

For the purpose of this analysis a modified leakage function is used in order to incorporate the reductive effect of buffer zone on nitrogen runoff $Z$

$Z=(1-j r) y(N)$,

where $\mathrm{Z}=$ nitrogen runoff, $\mathrm{y}(\mathrm{N})=$ nitrogen leakage at fertilizer intensity level $\mathrm{N}, \mathrm{kg} / \mathrm{ha}$, $\mathrm{j}=$ share of the surface runoff from combined surface and drainage runoff, and $r=$ nitrogen removal effectiveness of buffer zone.

Based on the Finnish experimental studies on grass buffer zones (Uusi-Kämppä and Yläranta 1992, 1996) and on the leaching of nitrogen (Turtola and Jaakkola 1985, Turtola and Puustinen 1998), we make the following assumptions. First $50 \%$ of the total nitrogen load is assumed to be 
Lankoski, J. \& Ollikainen, M. The environmental effectiveness of agri-environmental policy reforms

Table 2. Base simulation results. $30 \%$ of nitrogen runoff is abated. Simulations are government impactneutral and farm income-neutral. Parameter values are set at $\mathrm{y}_{\mathrm{n}}=15, \mathrm{j}=0.5$ and $\mathrm{r}=0.5$

\begin{tabular}{lcccc}
\hline & \multicolumn{2}{c}{$\begin{array}{c}\text { Government impact-neutral } \\
\text { simulation with parameter values } \\
\mathrm{y}_{\mathrm{n}}=15, \mathrm{j}=0.5 \text { and } \mathrm{r}=0.5\end{array}$} & $\begin{array}{c}\text { Farm income-neutral simulation } \\
\text { with parameter values }\end{array}$ \\
\hline Policy options & $\begin{array}{c}\text { Profit change } \\
\text { from the base } \\
\text { level (FIM/ha) }\end{array}$ & $\begin{array}{c}\text { Abatement costs } \\
\text { of reduced kg of } \\
\text { N (FIM) }\end{array}$ & $\begin{array}{c}\text { Increase in net } \\
\text { support per }\end{array}$ & $\begin{array}{c}\text { Net support per } \\
\text { abated N kg }\end{array}$ \\
& -199 & 40.7 & 15 hectare(FIM/ha) & (FIM) \\
\hline Policy mix 1 & -204 & 41.7 & 204 & 38.0 \\
Policy mix 2 & -121 & 24.7 & 121 & 41.7 \\
Policy mix 3 & -150 & 30.7 & 165 & 24.7 \\
Policy mix 4 & & & & 33.7 \\
\hline
\end{tabular}

Notes: Policy mix $1=$ Price support $\downarrow$ Buffer zone subsidy $\uparrow$; Policy mix 2 = Acreage subsidy $\downarrow$ Buffer zone subsidy $\uparrow$; Policy mix $3=$ Fertilizer tax $\uparrow$ Acreage subsidy $\uparrow$; Policy mix $4=$ Fertilizer tax $\uparrow$ Buffer zone subsidy $\uparrow$

a surface runoff, and second, a grass buffer zone 10 meters wide, is able to reduce $50 \%$ of total nitrogen from the surface runoff.

As in addition to fertilization intensity, precipitation and soil type are also important factors explaining the variation of nitrogen runoffs, these factors influence the parameter $y_{n}$ (nitrogen runoffs from average nitrogen use). Due to uncertainty relating to the effects of weather and hydrology on variation of $y_{n}$ and the nitrogen removal capacity of buffer zone, sensitivity analysis is conducted in order to investigate how robust the results and related policy implications are in the face of uncertain parameters.

Parameter values used for the simulations are reported in Table 1. A quadratic nitrogen response function for oats has been estimated by Bäckman et al. (1997) on the basis of the longterm field trials (1973-1993).

\section{Base simulation}

In the base simulation it is assumed that $50 \%$ of the total nitrogen load is surface runoff (i.e. parameter value $j$ is 0.5 ) and a grass buffer zone 10 meters wide, is able to reduce $50 \%$ of the total nitrogen of this surface runoff. Thus, pa- rameter value $r$ is set at 0.5 . Moreover, since in Finnish experimental studies combined surface and drainage nitrogen leakages $\left(\mathrm{y}_{\mathrm{n}}\right)$ at fertilization level $100 \mathrm{~kg} \mathrm{~N} / \mathrm{ha}$ have been in the order of $10-20 \mathrm{~kg} \mathrm{~N} / \mathrm{ha}$, parameter value $\mathrm{y}_{\mathrm{n}}$ is set at $15 \mathrm{in}$ the base simulation. Simulation results are reported in Table 2.

Table 2 shows that all policy mixes in the government impact-neutral scenario decrease the farmer's profits after the re-adjustment to new relative prices has taken place. This result is to be expected for two reasons. First, as the private solution in agriculture implies excessive nutritive pollution and, in this sense, excessive high production, achieving environmental targets requires less production and, ceteris paribus, lowers profits. Second, given that our model is a partial one, decreased production does not lead to a higher end price, which would compensate for the diminished revenue from lower production. Recall that in the theoretical section we showed that policy mix 4 was superior. It is not, however, the cheapest alternative for the average farm. Hence, if we add the requirement that even after re-adjustment the farmer's profits must be constant, the previous qualitative ranking changes as the farm revenue-neutral scenario indicates. Now policy mix 3 , in which the increase in the fertilizer tax is compensated for by 
Vol. 8 (1999): 321-331.

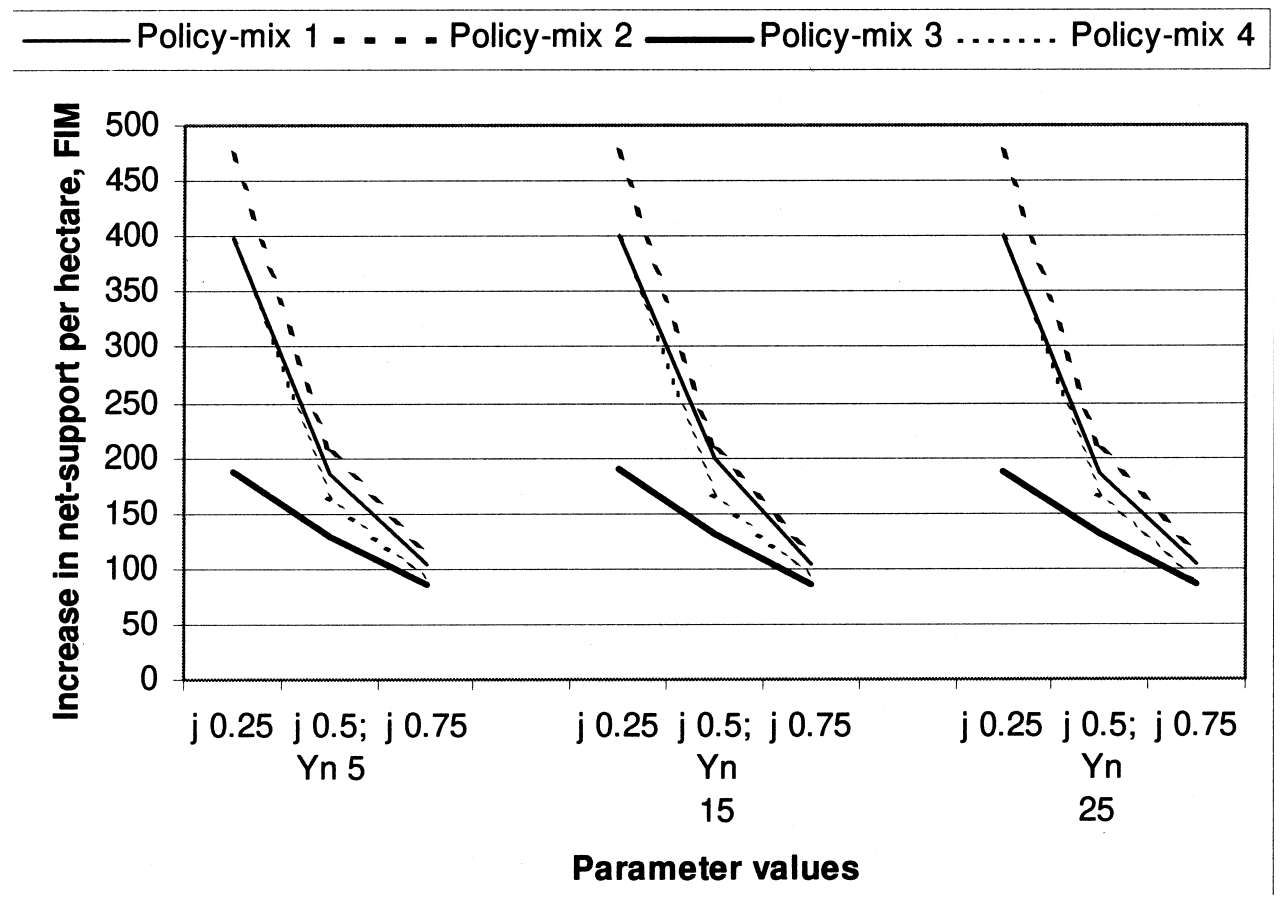

Fig. 1. Alternative policy mixes and the effect of different parameter values on increase in net support per hectare, FIM. Notes: Policy mix $1=$ Price support $\downarrow$ Buffer zone subsidy $\uparrow$; Policy mix $2=$ Acreage subsidy $\downarrow$ Buffer zone subsidy $\uparrow$; Policy mix $3=$ Fertilizer tax $\uparrow$ Acreage subsidy $\uparrow$; Policy mix $4=$ Fertilizer tax $\uparrow$ Buffer zone subsidy $\uparrow$. The value of $\mathrm{r}$ is 0.5 .

a higher acreage subsidy, seems the most promising in the sense that the loss of profits and the required additional net support from the government are the lowest.

\section{Sensitivity analysis}

Due to uncertainty relating to parameter values of $\mathrm{j}, \mathrm{y}_{\mathrm{n}}$ and $\mathrm{r}$, a sensitivity analysis was conducted in order to determine how robust the results are for the variation in the parameter values. The value of $r$ is set at 0.5 in the sensitivity analysis.

Sensitivity analyses show (Fig.1) that although the different parameter values have an effect on the additional amount of net support needed to keep the farmer's profit constant, the ranking of alternative policy mixes is not affect- ed by different parameter values. Policy mix 3 seems to be preferred option in every case.

\section{Conclusions}

The profit maximization model of a representative farmer showed that an acreage subsidy and a producer price support create environmental distortions, since they encourage the use of fertilization and discourage the allocation of arable land to buffer zone. Thus, when land allocation is endogenized through the choice of a buffer zone, an acreage subsidy becomes a distortionary instrument. This clearly contradicts the conventional wisdom, which regards it as a neutral 


\section{Lankoski, J. \& Ollikainen, M. The environmental effectiveness of agri-environmental policy reforms}

instrument. When alternative agri-environmental policy-mixes were theoretically evaluated from the viewpoint of environmental effectiveness, all analyzed policy options resulted in an unambiguously reduced nutrient runoff from agriculture. However, an environmental policy reform which compensates for the increase in the fertilizer tax by higher buffer zone subsidy had the strongest reductive effect on nutrient runoff since the fertilizer tax and buffer zone subsidy reinforced each other.

Base simulations of alternative policy mixes showed that the farmer's profit was decreased in every policy option. The criteria related to distortions on trade and production were fulfilled in every option. Policy mix 3 , that is an increase in fertilizer tax, which is compensated through an increasing acreage subsidy, however, resulted in the lowest increase in government net support and the smallest reduction in the farmer's profits. Sensitivity analyses showed that although the different parameter values had an effect on the additional amount of net-support needed to keep the farmer's profit constant, the ranking of alternative policy-mixes was not affected by different parameter values.

Acknowledgements. The authors would like to thank Jyrki Aakkula, Heikki Lehtonen, Jukka Peltola, Kyösti Pietola, Juha Siikamäki and three anonymous referees for their valuable comments on an earlier draft of this paper.

\section{References}

Bäckman, S.T., Vermeulen, S. \& Taavitsainen, V.-M. 1997. Long-term fertilizer field trials: comparison of three mathematical response models. Agricultural and Food Science in Finland 6: 151-160.

Braden, J.B. \& Segerson, K. 1993. Information problems in the design of nonpoint source pollution policy. In: Russell, C.S. \& Shogren, J.F. (eds.). Theory, modeling and experience in the management of nonpoint source pollution. Kluwer Academic Publishers, Boston, USA. p. 1-36.

Correll, D.L. 1997. Buffer zones and water quality protection: general principles. In: Haycock, N.E. et al. (eds.). Buffer zones: Their processes and potential in water protection. Quest Environmental. Harpenden, UK. p. 7-20.

Gilliam, J.W., Parsons, J. E. \& Mikkelsen, R.L. 1997. Nitrogen dynamics and buffer zones. In: Haycock, N.E. et al. (eds.). Buffer zones: Their processes and potential in water protection. Quest Environmental. Harpenden, UK. p. 54-61.

Hill, A.R. 1996. Nitrate removal in stream riparian zones. Journal of Environmental Quality 25: 743-755.

Ollikainen, M. 1995. Cost-efficient control of agricultural water pollution. In: Albisu, L. \& Romero, C. (eds.). Environmental and land use issues - an economic perspective. Proceedings of the $34^{\text {th }}$ EAAE Seminar. Wissenschaftsverlag Vauk Kiel KG. p. 75-88.

- 1999. On optimal agri-environmental policy: a public finance view. Kansantaloustieteen laitoksen keskustelualoitteita, no. 457. Department of Economics, University of Helsinki. 27 p.

Segerson, K. 1988. Uncertainty and incentives for nonpoint pollution control. Journal of Environmental Economics and Management 15: 87-98.

Simmelsgaard, S. 1991. Estimation of nitrogen leakage functions - Nitrogen leakage as a function of nitrogen applications for different crops on sand and clay soils. (In Danish: Estimering af funktioner for kvaelstofudvaskning. Kvaelstofudvaskning som funktion af kvaelstoftilförsel for forskellige afgröder dyrket på sandjord og lerjord) In: Rude, S. (ed.). Nitrogen fertilizers in Danish Agriculture - present and future application and leaching, Institute of Agricultural Economics Report 62 (in Danish: Kvaelstofgödning i landbruget - behov og udvasking nu og i fremtiden). English summary. Copenhagen. p 135-150.

Sumelius, J. 1994. Controlling nonpoint source pollution of nitrogen from agriculture through economic instruments in Finland. Agricultural Economics Research Institute Publications, No. 74, Helsinki. 66 p.

Turtola, E. \& Jaakkola, A. 1985. Viljelykasvin ja lannoitustason vaikutus typen ja fosforin huuhtoutumiseen savimaasta (in Finnish). Maatalouden tutkimuskeskus. Tiedote 6/85. Jokioinen. $43 \mathrm{p}$.

- \& Puustinen, M. 1998. Kasvipeitteisyys ravinnehuuhtoutumien vähentäjänä. Vesitalous 1/1998: 6-11.

Uusi-Kämppä, J. \& Yläranta, T. 1992. Reduction of sediment, phosphorus and nitrogen transport on vegetated buffer strips. Agricultural Science in Finland 1: 569-575.

- \& Yläranta, T. 1996. Effect of buffer strip on controlling erosion and nutrient losses in Southern Finland. In: Mulamoottil, G. et al. (eds.). Wetlands: environmental gradients, boundaries and buffers. Boca Raton: CRC Press/Lewis Publishers. p. 221-235.

Vatn, A., Bakken, L.R., Botterweg, P., Lundeby, Romstad, E., Rörstad, P.K. \& Vold, A. 1997. Regulating Nonpoint Source Pollution from Agriculture: An Integrated Modelling Analysis. European Review of Agricultural Economics 24(2): 207-229. 
Vol. 8 (1999): 321-331.

\title{
SELOSTUS
}

\section{Maatalouden ympäristöpolitiikkan reformien tehokkuus ravinnepäästöjen vähentämisessä - teoreettinen ja empiirinen analyysi}

\author{
Jussi Lankoski ja Markku Ollikainen \\ Maatalouden taloudellinen tutkimuslaitos ja Helsingin yliopisto
}

\begin{abstract}
Artikkelissa analysoidaan vaihtoehtoisten maatalouden ympäristöpolitiikan reformien tehokkuutta ravinnepäästöjen vähentämisessä, kun ohjauskeinoina voidaan käyttää tuottajahintatukea, lannoiteveroa, suojavyöhyketukea ja suoraa hehtaaritukea. Ympäristötavoitteiden saavuttamiseksi viranomaisen oletetaan sopeuttavan verojen ja tukien muutokset suhteessa toisiinsa niin, että viljelijän voitto ennen sopeutumista pysyy vakiona. Tämä politiikkamuutos johtaa ympäristön kannalta parempaan panoskäyttöön ja sitä kautta ympäristöystävällisempään tuotantoon. Analysoitavat neljä politiikkareformia ovat: tuottajahinnan tai suoran hehtaarituen vähentäminen, mikä korvataan viljelijälle lisäämällä suojavyöhyketukea, ja lannoi-
\end{abstract}

teveron lisääminen mikä korvataan viljelijälle lisäämällä joko suoraa tukea tai suojavyöhyketukea. Kaikki reformit vähentävät ravinnepäästöjä, mutta suurin päästöjen vähennys saadaan aikaan lannoiteveron ja suojavyöhyketuen yhdistelmällä. Simuloinnin tulokset osoittavat, että ravinnepäästöjen $30 \%$ vähennys pienentää keskimääräisen viljelijän voittoa kaikissa politiikkareformeissa, kun viljelijä on uudelleen optimoinut panoskäyttönsä vastaamaan verojen ja tukien uusia tasoja, ellei tuottajahinnan anneta nousta vähentyneen tuotannon johdosta. Lannoiteveron kompensoiminen suoralla hehtaarituella aiheuttaa pienimmän vähennyksen viljelijän voittoon. 